\title{
Democracy and Democratic Consolidation in Nigerian Fourth Republic: Issues and Challenges
}

\author{
Ahmed Babatunde Adeosun \\ College Of Foundation Studies\&Entreprenuership Education Hussaini Adamu Federal Polytechnic, Kazaure \\ P.M.B.5004, Kazaure, Jigawa State
}

\begin{abstract}
The present Fourth Republic came into being on $29^{\text {th }}$ May, 1999 when the then military head of state General Abdulsalam Abubakar handed over the rein of government to a democratically elected civilian president in person of Chief Olusegun Aremu Obasanjo. Democracy was embraced by Nigerians because of the belief that it would improve their living conditions. But alas! Since restoration of democratic rule, the body politic has become over heated by lots of challenges among which are insecurity, ethno-religious crises, corruption, electoral malpractice among others. This paper takes a critical look at democracy and democratic consolidation in Nigerian Fourth Republic. The paper relying on qualitative approach, using data obtained from secondary sources such as text book, journal articles, etc., analyses the challenges confronting democratic consolidation in the country. The paper contends that these challenges have negative effects on democratic stability and consolidation. The paper recommends among others, good governance which encompasses accountability, responsiveness and transparency on the part of the ruler; provision of employment to the teeming youth who are unemployed, among others.
\end{abstract}

Key words: democracy, democratic consolidation, political violence, prebendal politics, civil society

\section{Introduction}

Towards the end of the last century, Africa like the rest of the world witnessed the "third wave of democratization" when authoritarian regime and one party governments were replaced or supplanted by elected civilian governments or administrations. Nigeria described by Ette (2013) as one of the strongholds of dictatorship in the continent was caught in the snowballing effect of the wave after twenty-nine years of military dictatorship. After several years of failure attempt by the past military regimes of Ibrahim Badamasi Babangida and Sani Abacha, democracy formally gained root in the country on 29 May, 1999. Nigerians were full of hopes and expectations that hard earned democracy will usher in improvements in standards of living, good governance, improvement in security and what Mohammed (2013) described as freeing of natural resources from the iron fist and jaw of greedy officials to that of enterprising and efficient social services delivery in health, education, sports and prevention of modern day slavery such as human trafficking as well as rehabilitation of infrastructural facilities, poverty alleviation and reduction in unemployment, inequality and improvement in general socio-economic development.

Disturbingly, fourteen years after the inception of the present democratic dispensation, the political landscape is yet to show clear evidence of good governance. Elections and electoral processes are subverted; there have been wide scale of political violence and killing in many parts of the country; upsurge in ethnic militia groups who make life unbearable for the citizenry; general insecurity and high profile terrorism in the northern part of the country as well as kidnapping and bunkering of the petroleum pipelines in the southern part of the country.

It is against this backdrop that this paper examines and exposes the tragedy that has befallen the country under the present democratic dispensation. The paper seeks to provide answers to the following questions: What is democracy? What are the challenges confronting democratic consolidation in Nigeria? What are the prospects of democracy and democratic consolidation in Nigeria? The paper is structured into five sections of which this introduction is a part. The second segment delves on conceptual clarification of concepts such as democracy and democratic consolidation. The third section is the theoretical framework. For this paper, liberal theory of democracy has been adopted as our tool of analysis. The fourth section analyses the challenges of democratic consolidation in the country while the last section is the conclusion and recommendation.

\section{Conceptual Clarification}

It is important to attempt a clarification of the two important concepts which are germane to the understanding and explanation of this paper. These are the concepts of democracy and democratic consolidation. 


\section{Democracy}

Democracy has won for itself a household name across the globe. It has gained popularity because it is believed to be a sine-qua-non for growth and development. What then is democracy? There is no generally accepted definition of democracy because over the years, different forms of democracy have emerged. According to Erunke (2012), democracy is a fluid concept that has received many definitions by scholars either in the classical political studies or in the contemporary world of scholarship. According to Almond, Powell, Strom and Dalton (2004), democracy is a political system in which citizens enjoy a number of basic civil and political rights and in which their most important political leaders are elected in free and fair elections and accountable under the rule of law. For Lipset (cf. Dada et.al, 2013), democracy is a political system which supplies regular constitutional opportunities for changing the governing officials and a social mechanism which permits the larger possible part of the population to influence major decisions by choosing among contenders for political office. In the same vein Schumpeter (cf Dada et.al, 2013), sees democracy as a political method or type of institutional arrangement for arriving at political, legislative and administrative decisions. According to him, it is a method by means of competitive struggle for the peoples' vote and this competition for votes is the distinguishing character of the democratic method. For Dahl (1982:11), democracy is "a system of elected representative government operated under the rule of law, where the most significant groups in the population participate in the political process and have access to effective representation in the practice of making governmental decisions, that is, of allocation of scarce resources".

\section{Democratic Consolidation}

Democratic consolidation is one concept that has attracted the attention of scholars and policy makers since the advent of the third wave of democratization. According to Andreas Schedler (1998:101), democratic consolidation is "an omnibus concept, a garbage-can concept, a catch-all concept, lacking a core meaning that would unite all modes of usage". In the literature, there are two ways of viewing the concept of consolidation. Consolidation as avoiding democratic break down (Linz and Stephan, 1996) and consolidation as transformation from a diminished sub-type of democracy to a consolidated liberal democracy(Valenzuela, 1992).The former has to do with the process of stabilizing and maintaining the new democracies while the latter focused on the process of deepening, completing or organizing democracies(Shedler, 1998).

Despite the nebulous nature of the concept, most scholars accept the original understanding of the concept as being associated with the challenge of securing and extending the life expectancy of new democracies, of building immunity against the threat of regression to authoritarianism and reverse waves (Schedler, 1998). According to Diamond (1997), democratic consolidation represents a state whereby institutions, rules and constraints of democracy becomes the sole legitimate means for the acquisition and exercise of political power. For Jega (2006) cited in Erunke (2012), democratic consolidation is a term which describes the vital political goal for a transiting democracy with intermittent flop by authoritarian rule. It consists of overlapping behavioural, attitudinal and constitutional dimensions through which democracy becomes routinised and deeply internalised in social, institutional and even psychological life as well as political calculation for achieving success. Ademola(2011), conceives democratic consolidation as an identifiable phase in the process of transition from authoritarian to democratic system that are critical to the establishment of a stable, institutional and lasting democracy. Similarly, Beetham(1994), cited in Mohammed (2013) sees democratic consolidation as the challenge of making new democracies secure and extending their life expectancy beyond the short term of making them immune against the threat of authoritarian repression and of building dams against eventual reverse waves. For Frimpong- Mansoh(2012:14), democratic consolidation refers to "a firm establishment and successful completion of the process of political democratization". According to Ogundiya (2009), democratic consolidation is about regime maintenance and about regarding the key political institution as the only legitimate framework for political contestation and adherence to the democratic rules of the game. In the same vein, Mainwaring, et.al (1992), define democratic consolidation as the acceptance by all political actors that democratic procedure dictate government renewal. Put differently, democratic consolidation entails widespread acceptance of rules that generate political participation and competition. Linz and Stephan (1999:5) contend that in a consolidated democracy, "democracy becomes the only game in town" and offer a framework encompassing behavior and attitudinal and constitutional means of determining democratic consolidation. Behaviourally, there are no significant socio-economic, political, institutional or national actors trying to achieve their aims through unconstitutional means, violence or in attempt to secede from the state. Attitudinally, they argue that consolidation is achieved when a strong public opinion, privileges, democratic procedures and institution as the only appropriate means of governing. Constitutionally, in consolidated democracies, both government and non-state actors and social forces in the state become subjected to and abide by laws, procedure and sanctioned institutions for conflict resolution. Hence, although there may be severe problems of governance, and widespread dissatisfaction of the ruling government, the public and the elites uphold the belief and commitment to constitutional means as the only 
legitimate way to change a government. Huntington (1991), on his part, postulates a "two- turnover" thesis as an indicator of democratic consolidation. He argues that democracy becomes consolidated when an entrenched regime delivers free, fair and competitive election by which the party that wins power at the initial elections during the transition phase loses in subsequent elections and hands over power to the winning party and when the winning party also in turn hands over power peacefully to another party at subsequent elections.

\section{Theoretical Framework}

The paper adopts liberal theory of democracy in analyzing democracy and democratic consolidation in Nigerian Fourth Republic. The liberal theory of democracy is common among capitalist countries such as United States of America, Britain, France, etc, as well as peripheral capitalist countries such as Nigeria, Kenya, South Africa, etc. Put differently, Liberal democracy describes the form of democracy prevalent in western politics and gaining adherents throughout the globe. This idea of democracy emerged when capitalism became the dominant mode of production in Europe and North America. The major exponents of this theory are: John Locke, J.J. Rousseau, John Stuart Mill, Adam Smith, Baron De Montesquieu, etc. The essential features of this theory are listed below:

$>$ Acceptance of capitalism

$>$ Competitive party system as opposed to one party system

$>$ Rule of law

$>$ Pressure groups

$>$ Separation of powers and checks and balances

$>$ Emphasis on civil liberties or individual rights such as freedom of speech, assembly, press and religion

$>$ Free, fair and periodic elections based on universal franchise

$>$ Abhorrence of revolutionary approach to change of government (Mohammed, 2013: 573-574; Kwasau, 2013:183).

Essentially, liberal theory of democracy sets-out to design a political system which encourages individual participation and enhances moral development of the citizens. It grants all adult citizens the right to vote and be voted for regardless of race, gender or property ownership. The utility of this theory as a framework of analysis is that it helps to examine analytically democracy and democratic consolidation in Nigerian Fourth Republic, as it designs the systematic structure through which a democratic political system can function effectively and efficiently. Besides, it exposes and explains the expectation of any political system, especially as it relates to the conduct of credible election which is one of the factors responsible for consolidating democracy. The liberal theory of democracy has come under fire from critics. It has been criticized on the grounds that it does not respect absolute majority rule (except when electing representatives). The liberty of major rule is restricted by the constitution or precedent decided by previous generations. Also, the real power is held by a relatively small groups or representative in the society. It has also been criticized on the grounds that it is merely a decoration over an oligarchy. For Marxist, Socialist and left wing Anarchists, liberal democracy is an integral part of capitalism. Therefore, it is a class based and not democratic or participatory. For non-democratic socialist, it is a honest force used to keep the masses from realizing that their will is relevant in the political process. Besides, liberal democracy is an expensive form of government. Democracy means organisation of opinion, propaganda and frequent elections. All this involves huge expenditure. Money which should be used for productive purposes is spent on electioneering and nursing the constituencies (Asirvatham and Misra, 2009). Although other theories such as elitist theory of democracy, the pluralist theory of democracy, classical theory of democracy, political-economic theory and Marxist theory of democracy could have been used to explain this studies, none is sufficient enough to analyse democratic consolidation better than the liberal theory of democracy.

Challenges of Democratic Consolidation in Nigerian Fourth Republic

The challenges confronting democratic consolidation in the country are numerous. Some of these are examine below:

\section{Electoral Malpractice}

One of the tenets of democracy is orderly change of government through credible free, fair and periodic elections. Since restoration of democratic rule in the country, change of government has been orderly while elections have been periodic. Between 1999 and 2011 three different civilian administrations have emerged and there have been three successive transitions from civilian government to another (Obasanjo Administration, 1999-2007, Yar'adua/Jonathan Administration, 2007-2011; Jonathan Administration, 2011 till date). This also applicable to the legislature. Since 1999, the country has successfully passed through three legislative houses both at the centre and the component units. Elections in the Fourth Republic have been characterized by monumental irregularities and malpractices which magnitude increases with every election. Institutions of state 
such as the police, the military, and the electoral body collude to manipulate the electoral process in favour of certain candidate. Apart of election being one of the cardinal principles of democracy or democratic process, free, fair and credible elections are central to the consolidation of democracy. This is because, it defines the degree of freedom exercised by the people in selecting who represent them in government. But this has not been the case in Nigeria as the system is manipulated in favour of certain individuals and political parties (Ogbonnaya, Omoju and Udefuna, 2012).

\section{Poverty}

Poverty is another factor that constitutes grave challenges to democratic consolidation in the country. Nigeria is blessed with abundant human and natural resources and yet its people are poor. The nation is rank among the world's poorest country. According to United Nations Development Programme (2009), in Nigeria hunger exhibits its ugly face in most homes where the average citizen contends with a life of abject poverty. Thus, the average Nigerian is alienated from himself as he lacks the wherewithal to afford the basic necessities of life such as education, medical facilities. According to Victor (2002) cited in Ogbonnaya, et.al (2012) about $70 \%$ of Nigeria population are poor. The consequence of this is that the poor masses are easily brainwashed and their right of choice terribly manipulated making an objective choice seldom to consideration. Besides, various forms of inducements and gratification which provide temporary relief from the scourge of poverty are given central attention in making democratic choices. Poverty has also been identified by some scholars as one of the causes of security challenges confronting the nation (Awoyemi, 2012; Harrington, 2012).

\section{Corruption}

Corruption constitutes one of the greatest challenges and threats to the democrat consolidation in Nigeria Fourth Republic. The incidence of corruption in the country reached a crescendo in2004 when a German based non-governmental organisation called Transparency International in its 2004 Corruption Perception Index(CPI), report projected Nigeria as the 2nd most corrupt country in the world(132nd out of 133 countries surveyed) (Akinyemi, 2008). Nigeria has also been ranked as the 3rd most corrupt country in the SubSaharan Africa and 143rd out of 183 countries surveyed around the world in 2011( Transparency International, 2011). According to the Transparency International(2011), the level of corruption and other related crimes in the country attracted between $\$ 4$ million and $\$ 8$ million dollars loss on daily basis and a loss of about $\$ 70.58$ million dollars to the national economy annually and that the country has lost more than $\$ 380$ billion to graft since the country attained independence in 1960. It has been argued that the war on graft has been difficult to win because the act is perpetrated by policy makers themselves (Olu-Olu, 2006; 2008). A clear indicator to this fact is the US\$620, 000 oil subsidy bribery scandals rocking the National Assembly and the latest one is the two armoured cars bought by the National Civil Aviation Authority(NCAA) at a cost of \#255million for the Aviation Minister Stella Oduah (The Nation, 2013). According to Oko(2008), nothing enervates democracy more than corruption. It not only distorts governance but also provides perverse incentives for dysfunctional behavioural as well as diminishes the quality of life of the citizen by diverting funds for social service into private pockets.

\section{Incumbency factor}

Incumbency gives the incumbent an undue advantage over other participants in the electoral process through the means of manipulating the entire electoral process. The manipulation can take different forms ranging from compilation of voters' register, the appointment of electoral officers, members of electoral tribunal to protect stolen mandates, use of state instrument of coercion and apparatus to intimidate opposition parties and denial of access to state owned media houses, etc, to ensure they regain or elongate their tenure against popular will as well as the use of state funds for campaign. The cumulative effect of incumbency factor on democratic consolidation is that it leads to the erosion of the principle of democratic governance which has led to the emergence of political godfather and family dynasty (Nwanegbo and Alumona, 2011).

\section{Lack of viable Opposition Parties}

Since the inception of this republic, there has been no viable and credible opposition party capable of checkmating the ruling party. Opposition parties are vital in every functional and people oriented democratic government. This is because they checkmate the excess of government or its agencies by highlighting constitutional rules and appropriate principle and practice in democratic governance. Nigeria's political environment has been dominated by the People Democratic Party since restoration of democratic rule in 1999. Although the country has over fifty political parties, most of them are very weak to provided needed opposition to the ruling party at the centre. Thus, the absence of viable opposition in today's Nigeria democratic system left the ruling party to call the shots on most national affairs (Njoku, 2012). 


\section{Insecurity}

One of the daunting challenges confronting the present democratic dispensation is insecurity. Since the return of democracy, the country has experienced ethno-religious crises, sectarian mayhem, etc., questioning and shaking the survival of the country. Some of these crises include: Yoruba/Hausa-Fulani disturbance in Shagamu, Ogun State; Aguleri, Umuleri and Umuoba Anam of Anambra State; Ijaw/Itsekiri crisis over the location of Local Government headquarter; the Jukun, Chamba and Kuteb power struggle over who control Takum; incessant turbulence in Jos; the 2011 post-election violence in the northern part of the country as well as the constant sectarian crisis exemplified by the activities of the Boko Haram. The analysis of the above upheaval will reveal that our democracy is under siege prompting Dauda and Avidime (2007 to argue that the current security situation in the country is a major obstacle to the consolidation of democracy.

It is important to note that despite these challenges there is a light at the end of the tunnel. After fourteen years of uninterrupted democracy, the longest in the history of the country. Nigeria can be said to have arrived democratically. There abound significant elements of democratic consolidation in the political system and these are: vibrant press, independent judiciary and a budding civil society as well as widespread acceptance of elections as a means of choosing political leaders.

\section{Incidence of Political Thuggery}

The widespread incidences of political thuggery in the present democratic dispensation constitute a threat to democratic consolidation in Nigeria. It is widely believed that thugs were usually hired, maintained and equipped by some politicians to subvert the electoral process to their utmost political advantage. In addition, thugs by their modus operandi (mode of operation) are predisposed to intimidate, harass or even harm the opponents of their sponsors. For instance, in Oyo State during the days of strongman of Ibadan politics Chief Lamidi Adedibu (a.k.a Garrison Commander), he was reputed to have maintained a battalion of thugs who only needed his fingers to spur them into actions (Iwere, 2009). His philosophy of and style of politics called Amala politics as well as his alleged state support and protection gave rise to his political excesses, arbitrariness and lawlessness in Ibadan and Oyo State in general(Njoku, 2010).

\section{Conclusion and Recommendation}

The paper examined and analysed the tragedy that has befallen the country since restoration of democratic rule on 29 May, 1999. The two concepts (democracy and democratic consolidation) which are germane to this discourse were thoroughly examined. The paper also analysed the challenges confronting democracy and democratic consolidation in the country. Some of challenges discussed include: electoral malpractice, poverty, corruption, incumbency factor, lack of viable opposition and insecurity. The paper posited that there was light at the end of the tunnel because of the presence of elements of democratic consolidation such as vibrant press, independent judiciary, budding civil society as well as acceptance of elections as a means of choosing political leaders.

\section{Recommendations}

The paper recommends the following as a way out of the observed challenges confronting democracy and democratic consolidation in the country.

- Deepening of democratic principle: Democracy is characterized by adherence to the rule of law, respect for fundamental human rights and the protection of life and property. For democracy and democratic consolidation to thrive in the country, the principles of democracy must not only be imbibed but must also be deepened.

- For democracy to be consolidated in the country, there is need for change in the value orientation of the political elite. The ideological bases of our political parties that facilitate political vagrancy must be altered. Besides, the National Assembly should enact a law to outlaw carpet-crossing.

- The war on corruption must be pursued with vigour. Put differently, it must be pushed beyond political propaganda, intimidation and witch-hunting of political opponents. Government must muster the political will to punish any corrupt public officer irrespective of his or her status in the society. In addition, legislation should be enacted by the National Assembly making capital punishment a penalty for corruption related offences.

- Democracy does not thrive on an empty stomach and democracy cannot be consolidated when majority of the people live in abject poverty. Governments at all levels need to be serious or pay more attention to problem of poverty. The socio-cultural factor such as family system that appears to be reinforcing poverty has to be addressed. Governments at all levels must pursue vigorously programmes that can alleviate poverty. Such programmes must address the roots cause of poverty. Besides, our educational sector should be overhauled. The curriculum should be such that addresses the present reality. 
- One of the tenets of democracy is orderly change of government through free, fair and periodic election. Elections in the periodic under review have not been free and fair. All hands must be on deck in order to ensure that our subsequent elections are credible, free and fair. The election management body must be truly independent in terms of finance and administration and should sanction any erring members found to have been involved in election malpractice. Furthermore, security operatives involve in election must be up and doing. Electoral offenders should be prosecuted to serve as a deterrent to others.

\section{References}

[1]. Ademola, A. (2011), Endangering good governance for sustainable democracy: The continuing struggle against corruption in Nigeria. Journal of Research on Peace, Gender and Development 1(11). December. Pp- 307-314.

[2]. Akinyemi, B (2008), Corruption a battle Nigeria must win. Thisday, August 22. P22.

[3]. Alli, Y. (2013) N255 million car scandal: Oduah's 12 sins by reps panel. The Nation on Sunday November. 10, P.5

[4]. Almond, G.A.; Powell, G.B.; Strom, K. \& Dalton, R.J.(eds) (2000), Comparative Politics Today: A World View. Singapore: Pearson Education, Inc.

[5]. Asirvatham, E. \& Misra, K.K. (2009), Political Theory. New Delhi: S. Chard \& Company Ltd.

[6]. Awoyemi, O. (2012), Revenue allocation, insecurity and poverty in Northern Nigeria Retrieved www.proshaven com/news/16703.

[7]. Babatope, A. O. (2012), Party conflicts and democracy consolidation in Nigeria: Bumpy past, Research in Arts and Social Sciences Vol. 1 No.1 June. Pp.12-20

[8]. Dada, J.A; Udoaka, E.E.; \& Dada,E.O(2013), The Imperative of good governance for sustainable African Journal of Social Sciences.Vol.3 No.2 pp 45-60

[9]. Dauda, O \& Avidime, S(2007), Towards a sustainable democratic government in Nigeria's fourth Journal \& International Studies.

[10]. Diamond, L (1997), Civil society and the development of democracy. Working Paper No. 101.

[11]. Erunke, C.E (2012), Reconsolidating democratic governance in Nigeria: Analysis and suggestions. Sciences Vol.2.No.2 pp. 67-73.

[12]. Ette, M(2013), The press and democratic consolidation in Nigeria: Prospects and challenges. November, 2013 from http://eprints/hud/ac.uk/id/eprints/18259. [13]. Frinpong-Mansoh, Y.A. (2102) Democratic consolidation in Ghana: The role of the news media. Africa Media and Democracy Conference, Accra, Ghana. Pp. 1-36.

[14]. Harrington, E. (2012), Religion is not driving extremist violence in Nigeria, says Obama officials, after church bombing, CNS News Retrieved on $17^{\text {th }}$ October, 2013 from www.cncnews/news/artcle/.../

[15]. Huntington, S.P (1991), The third wave: Democratisation in the late twentieth century. Norman: Press.

[16]. Kwasau, M.A. (2013), The challenges of democratic consolidation in Nigeria's Fourth Republic. March Edition, vol. 9 No. 8 Pp 181-192.

[17]. Linz, J.J \&Stephan, A (1999), Problems of democratic transition and consolidation: Southern post-communist Europe. Baltimore and London: The John Hopkins University Press.

on $17^{\text {th }}$ October, 2013 from shaky future. Journal of democracy in Nigeria. republic. Millennium Estudio. African Journal of Social Retrieved on $11^{\text {th }}$ Mainwaring, S., O’Donnell, G. and J.S. Valenzuela (eds)(1992), Issues in democratic democratic in comparative perspective. Notre Dame: university of Notre Dame Press.

[19]. Mohammed, U (2013), Nigeria's elected system: A change to sustainable democracy in the fourth republic. International Journal of innovative Research and Development Pp. 567- 581. Available at www.ijird.com

[20]. Njoku, A.O (2010), Political violence and its implications to democratic consolidation in Nigeria. Knowledge Review 21(4). December. Pp 16-22

[21]. Nwanegbo, C.J \&Alumona, I.M (2011), Incumbency factor and democratic consolidation in Nigeria's fourth republic. The Social Sciences 6(2) pp. 125-130.

[22]. Ogbonnaya, U.M., Omoju, O.E. \& Udefuna, N.P. (2012), The Challenges of democratic government in Nigeria's fourth republic. Mediterranean Journal of Social Sciences vol. 3 (11) November Pp. 685-693.

[23]. Oko, O. (2008), The challenge of democratic consolidation in Africa. From the selected works of Okehwawu Oko. www.works.bepress/okechukwu/oko/2

[24]. Olu-Olu (2006), Corruption and the problem of development in Nigeria. The social Science, (3), 183-187.

[25]. (2008) Corruption by example: Legalising the illegal as a means of survival in modern Nigeria. Bangladesh e-Journal of Sociology 5(1) January.

[26]. Shedler, A (1998), What is democratic consolidation? Journal of Democracy, 9(2), pp 91-107.

[27]. Valenzuela, S.J. (1992), Democratic Consolidation in Post-transitional settings: Notion, Process and facilitating conditions In S. Mainwaring, G: O'Donnell and J.S. Valenzuela (eds) Issues in democratic consolidation: The South American democratic in comparative perspective. Notre Dame: University of Notre Dame Press. Pp.57-103. 